DOI 10.31718/2077-1096.21.2.190

УДК 378:159.943.7:316.772.3]:61-057.875"376:45*1"

Ivanchenko O.Z., Melnikova O.Z., Lurie K.I.

\title{
ASSESSMENT OF ESSENTIAL COMMUNICATIVE SKILLS OF FIRST YEAR MEDICAL STUDENTS
}

Zaporizhzhia State Medical University

The purpose of the presented work is to assess the development and progression of basic communication skills of the 1st year students of the medical faculty that can serve as the basis for their further improvement over the course of professional education. The general level of students' communication skills was assessed using the test "Diagnosis of communicative and organizational tendencies"; the general level of empathy and the degree of its manifestation in communicating with different categories of people were studied using the Yusupov I. test; types of behavior in conflicts were estimated using the Thomas test. The research findings were processed according to the keys suggested by the authors of the tests. The study has shown that the majority of students (66\%) demonstrates a high and very high level of general communication, while $18 \%$ of participants have low and very low levels of communication skills. An adequate general level of empathy was found in $91.7 \%$ of 1 st year students, moreover, it was high in the remaining $8.3 \%$ of students. All respondents have shown the greatest empathy towards parents (average level 10.1 out of 15 possible scores), strangers (9.2) and children (8.9), while the level of empathy for older people was 6.9 points. Determining the strategy for resolving conflict situations has revealed that 1 st year students most often choose a compromise (22.5\% boys and $24 \%$ girls), the strategy of avoidance ranks the second position and is commn among the girls (23\%, while the boys exhibit rivalry (21.8\%), cooperation is chosen mainly by the girls (19.8\%). The results of the study have shown that high levels of general communication and empathy could contribute to the choice of a future profession by the students and need only the right support during their graduate training program. Much attention should be paid to fostering empathy for the elderly people and the choice of cooperation as the best conflict resolution strategy between the parties during educational process at the university.

Key words: 1st year students, communication, empathy, conflict situations

The curricula of medical educational settings establish a set of the main competencies, which students should master during their training period. Among the most important knowledge and skills to be acquired by future medical doctors including medical theory and knowledge, patient care and procedural skills, professionalism and others, interpersonal and communication skills are known to play an important role as well. They presuppose a person's ability to interact with other people, to adequately interpret the received information, to transmit it correctly. Climbing up the carer ladder in medical profession is hardly possible without effective communication as it reflects healthcare professionals' personal values and interpersonal skills and they also contribute to the successful provision of health care. Communication between a doctor and a patient is the basis for obtaining information about the diagnosis, the effects of treatment methods, etc. Moreover, in their medical practice, doctors have to communicate not only with patients but with their relatives, as well as colleagues on regular daily basis. Therefore, the development of interpersonal and communication skills is a mandatory prerequisite for the successful career of healthcare professionals, and the investigation of the communication skill levels as well as approaches towards their improvement is one of urgent scientific and practical pedagogical issues.

The problem of communication in the field of health care is in the focuse of close attention of the medeical, philological and pedagogical community, both in Ukraine and abroad [1-4, 8-12].

Communication skills are one of the main criteria for the perception and assessment of the level of qualification of healthcare workers by patients, who, first of all, mainly assess the "doctor's attitude", followed with "treatment outcomes", and only after that "experience", "feedback from other patients" etc. [1]. According to researchers, professional effectiveness is determined by the following communication skills: "communicative self-control, tolerance, empathy, the ability to establish contacts, listening skills, attentiveness, openness, ability to prevent conflict, desire to help and focus on social benefits, and eagerness to cooperate" [2].

The important role of communication skills in the medical profession determines the relevance of the study of their fostering in students of medical institutions at different stages of education. It can be especially useful for first-year students, as it provides great opportunities for teachers to pay considerable attention to the development and improvement of this competence.

The purpose of this study is to assess the development and progression of basic communication skills of the 1st year students of the medical faculty, including the general level of empathy and types of behavior in resolving conflicts.

\section{Research methods}

The methodology of this theoretical study included the analysis and generalization of psychological and pedagogical, scientific and methodological literature; empirical methods as questionnaires, testing (test "Diagnosis of 
communicative and organizational tendencies (COT-2)", test to determine the empathic potential of the individual by Yusupov I., Thomas test "Types of behavior in conflict situations"). The test findings were processed according to the keys provided by the authors.

When using the test «Diagnosis of communicative and organizational tendencies (COT-2)», students assessed themselves independently. A total of 80 people were interviewed. The students were asked to examine forty "yes / no" questions, twenty of which had been designed to assess the development of communication skills, and the other twenty - to assess organizational skills. According to the sample distribution of scores, the answers related to the evaluation of communicative tendencies were separated, and the levels of their development and the percentage of the students with having particular levels were determined.

According to the test of determining the empathic potential of the individual by Yusupov I., the general level of empathy was determined, as well as the degree of its expression in communication with the family, the elderly people, children, strangers, in the treatment of animals. The results were obtained from 78 people.The student could score from 0 to 15 to assess each of the suggested situations, and then we determined the average level of empathy in all respondents.
The study of conflict avoidance strategy was conducted by using the Thomas test "Types of behavior in conflict", which identifies five ways to manage conflicts, marked according to two fundamental dimensions: cooperation, which involves a person's attention to the interests of others parties involved in a situation, and assertiveness, which is characterized by an emphasis on their interests: 1. Competition, defined as a desire to achieve their interests to the detriment of others; 2. Adaptation, defined as sacrificing one's interests for the sake of another; 3 . Compromise, agreement based on mutual concessions; proposing an option that removes the contradiction; 4. Avoidance, a lack of desire for cooperation and lack of tendency to achieve their own goals; 5 . Cooperation, when the participants of the situation come to an alternative that fully satisfies the interests of both parties. 18 boys and 49 girls were involved in the survey. In both groups, the percentage of students who chose each type of conflict avoidance strategy was determined.

\section{Results and discussion}

Using the test «Diagnosis of communicative and organizational tendencies (COT-2)», we identified five levels of the development of communicative abilities: the highest, high, moderate, low, very low (Picture 1).

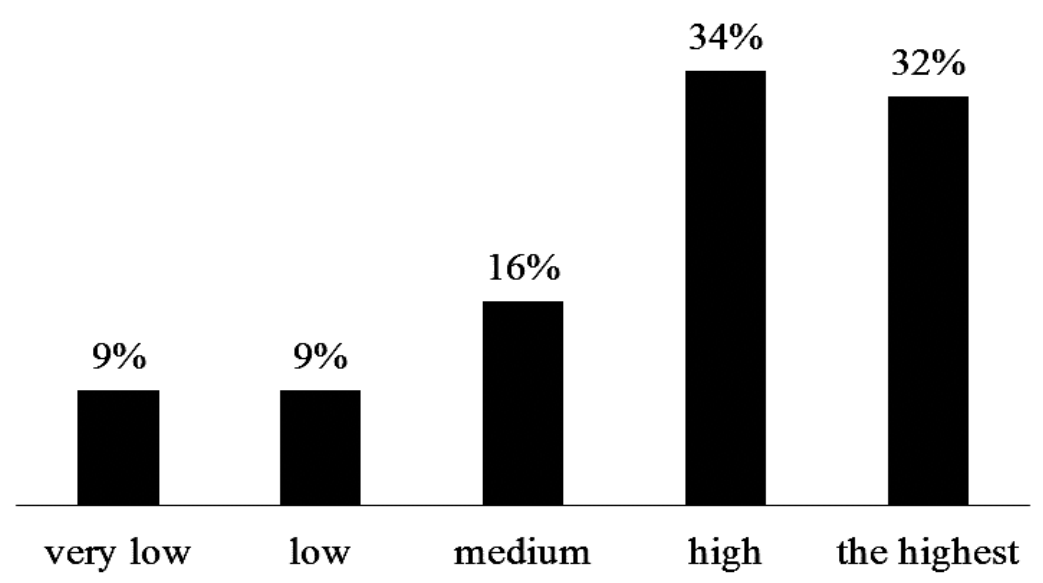

Picture1. The number of students with different levels of communication skills among all respondents

Picture1. The proportions of different levels of communication skills among all respondents

According to the survey, most students, in their opinion, have a high $(34 \%)$ and very high $(32 \%)$ levels of communication skills. They noted that it is easy for them to make new contacts and find friends, they seek to expand their social circle and are happy to help family and friends. Quite often such students take the initiative in communication. In the new circumstances, people with a high and very high level of communication skills quickly navigate difficult situations, are not lost, and can make decisions in complex or atypical cases. The participants, who have the highest level of communication skills, describe themselves as those who endeavour to communicate. They behave casually in a new team, are proactive, can make independent decisions, defend their opinions, and seek to make their decisions.

A total of $18 \%$ of respondents acknowledged a very low and low level of communication skills. Such students do not seek chances to communicate, prefer to spend time alone with themselfs; they feel trapped in a new company or team, have difficulty establishing contact with people, do not defend their opinion, have difficulty in dealing with offenses, rarely show initiative, avoid making independent decisions. 
The next stage of the study was to determine the level of empathy of students, which is one of the most important communication skills necessary for the successful work of a doctor. As you know, empathy is the ability to emotionally feel the state of another person, the ability to sympathize, feel for, and treat the other person humanely. Several test surveys that can be used to determine the level of human empathy (Boyko V., Kindratyuk S., LytvynV., I. Yusupov I., and others). To determine the empathic potential of students, we used the method of Yusupov I., which allows us to assess the overall level of empathy, as well as the degree of its expression in communication with different people and the treatment of animals.

The obtained results show that $91,7 \%$ of students have a normal general level of empathy. This means that «in interpersonal relationships, such people are more likely to judge others by their actions than to trust their impressions"[7]. For others, such people are not particularly sensitive, but it is impossible to call them indifferent. Respondents admitted that they try not to impose their point of view, and it is often difficult for them to predict certain actions of others. The full perception of people is hindered by some rigidity of feelings. The students try to understand or feel what other people are experiencing, and are attentive in the process of communication. This level of empathy is optimal because such individuals have strong emotions, demonstrate a strong tendency to empathize and compassionate, have a high level of sensitivity and emotional response, they display the right reactions to other people's moods, regardless of gender and age [8].

$8.3 \%$ of the first-year medical students were assessed as having high empathy level. Such people are "sensitive to the needs and problems of others, generous, inclined to forgive them a lot. They have a real interest in people, are emotionally sensitive, sociable, quickly establish contacts and find common ground with them. People around them appreciate them for their sincerity, ability to find compromise solutions, adequate perception of criticism. They prefer to work together with people than to work alone, they constantly need social approval of their actions; they are quite easy to throw off balance. Often such people are inaccurate in painstaking work or work, which requires a high level of attention [7]. It should be noted that a high level of sensitivity, the ability to feel the nuances in the moods of others, a high emotional response, can sometimes lead to internal devastation, depression [8].

Yusupov's test allows us to analyze the level of empathy to different categories of people, as well as to animals. According to the results of our study (Picture 2), it was found that students feel the greatest empathy to parents (average level 10.1), strangers (9.2), and to children (8.9). The participants noted that they felt less compassion for the elderly than for others (average level 6.9).
However, it should be pointed out that the level of empathy under certain conditions may decrease or, conversely, increase [8], i.e. this indicator is quite unstable. In this regard, in our opinion, an important component of medical education should include the purposeful fostering of empathy of future doctors to all people.

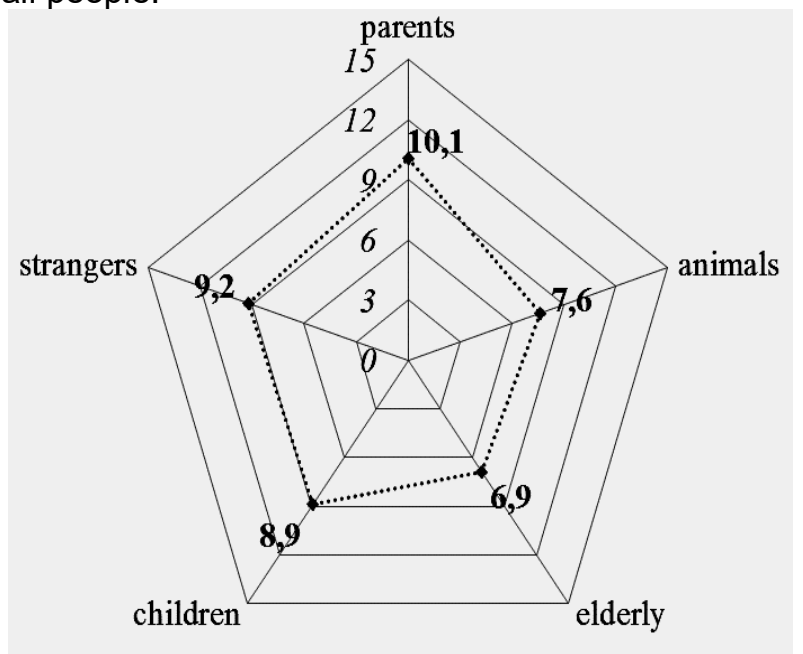

Picture 2. Levels of empathy of students to surrounding people and animals according to the test of Yusupov $l$.

When determining the strategy of avoiding conflict situations using the Thomas test «Types of behavior in conflict», we found that among the firstyear students compromise slightly prevails in conflict resolution: it was chosen by $22.5 \%$ of the boys and $24 \%$ of the girls. This strategy is characterized by the search for a balance of mutual concessions and gains. For the sake of understanding, the parties agree to partially satisfy their needs to maintain the relationship and get at least something. At the same time, there is a shadowing of contradictions and emphasizing common interests. Sometimes compromise is the last chance to make a decision [6].

Avoidance rakns the second place among the girls $(23 \%)$, i.e. they demonstrate passive behavior in a conflict situation that consists of ignoring the problem, postponing their intervention. This is a desire to avoid acute situations and not to discuss issues that are the subject of controversy. They also prefer the tactics of presence without signs of active intervention, maintaining neutrality, and not disclosing their views and attitudes to the problem. The parties are allowed the opportunity to make their own choices and be responsible for their own choices. Thomas believes that if the conflict is avoided, neither side will succeed.

Tne boys $(21.8 \%)$ choose rivalry to resolve conflicts that is the second most common option. The party of the conflict, applying the style of rivalry, tries to impose its version of the dispute or vision of the situation. Own victory is seen as the defeat of the enemy. Tactics of pressure and threats are used in the negotiations, attempts are made to question the competence of opponents, a weak point in their argument is sought, as a rule, 
there is also a tendency to unappealable statements, a negative attitude towards those who have a different opinion. In behaviors such as competition, adaptation, compromise, either one wins and the other loses, or both lose because they make concessions to each other.

The best way to resolve the conflict, according to Thomas K., is cooperation, when contradictions are clearly discussed and all parties are persistently looking for the best solution to the dispute [6]. The girls are more inclined to cooperate (19.8\% of all respondents).

The results of our study have shown that among the basic communication skills of the first-year medical students the most developed ones are general level of communication and empathy. However, some students have some problems with these skills. This is especially true of students' empathy for older people, with whom they will have to work largely in the future profession for objective reasons. It is also necessary to teach students the strategy of cooperation in resolving conflict situations as we have found out that this strategy is applied only by some first-year students.

In practice, the doctor must develop communication techniques, which help them build up relationships with different people regardless of personal qualities (level of empathy, attitude to criticism, behavior during conflict, the degree of introversion, and others). Practicing and improving the communication skills is a necessary condition for creating a comfortable environment not only for patients but also for themselves: in an atmosphere of trust and respect for others, doctors solve their professional and personal problems more effectively. Obviously, it is impossible to choose among practicing physicians only those whose personal characteristics are to promote communication. But the doctor should know that the improvement of communication techniques allows them to diagnose diseases more accurately, to boost compliance, i.e. to increase the commitment of patients to follow doctor's recommendations and thus, to achieve the best treatment outcomes, to enhance patient's satisfaction with medical care, amd to prevent possible conflicts and claims. Over time, positive feedbacks about such doctors are showing increase among the patients, colleagues, the administration of the healthcare settings that in turn significantly boosts the reputation of the specialists as true professionals. Also, it is very important that with effective communication between all participants in the process, doctors maintain their own mental and physical health that prevents burnout syndrome.

\section{Conclusions}

1. One of the competencies that a future doctor should gain during the professionat training period is a high level of communication skills, which must be acquired at a medical university based on the already built up skills fostered during the previous life period.

2. Most first-year medical students demonstrate high levels of communication and general empathy that probably contributed to their choice of future profession.

3. Levels of students'empathy for certain categories of people are different. That could be largely due to the first year of their higher education and this may change in the future, especially during the purposeful fostering of students' communication skills.

4. The strategy of conflict resolution in the form of cooperation between the parties as the best option is represented by a small proportion of the first-year students, and therefore needs further improvement over the course of their study.

In the future, we plan to continue studying the approaches to improve communication skills of firstyear medical students by assessing their selfcontrol and attitude to criticism.

\section{References}

1. Haliyash NB, Bil'kevych NA, Petrenko NV. Formuvannya komunikatyvnoyi kompetentnosti yak fundamental'noyi skladovoyi profesiyi likarya [Formation of communicative competence as a fundamental component of the medical profession]. Medychna osvita. 2019; 2: 67-74. (Ukrainian)

2. Dronenko $\mathrm{VH}$. Doslidzhennya komunikatyvnoyi kompetentnosti maybutnikh likariv [Research of communicative competence of future doctors]. Medychna osvita. 2018; 4: 41-46. (Ukrainian)

3. Yusef YUV. Teoretychni zasady formuvannya komunikatyvnoyi kompetentnosti maybutnikh likariv [Theoretical bases of formation of communicative competence of future doctors]. Pedagogical process: theory and practice. 2013; 3: 187-194. (Ukrainian)

4. Filonenko MM. Psykholohiya spilkuvannya [Psychology of communication]. Kyiv; Tsentr uchbovoyi literatury. 2008: $224 \mathrm{p}$. (Ukrainian)

5. Test "Diahnostyka komunikatyvnykh i orhanizators'kykh skhyl'nostey (COT-2) [Test "Diagnosis of communicative and organizational tendencies (COT-2]. Available from: organizational tendenci

6. Test «Vyznachennya stylyu povedinky v konfliktniy sytuatsiyi» (za metodykoyu K. Tomasa) [Test "Determining the style of behavior in a conflict situation" (according to the method of K. Thomas]. Available from: https://osnova.com.ua/news/739

7. Test na vyznachennya empatiynoho potentsialu osobystosti I.M.Yusupova [Test to determine the empathic potential of IM I.M.Yusupova [Test to determine the empathic potential of IM
Yusupov's personality]. [Internet] Available from: https://psytests.org/emotional/yusupov-run.html

8. Kotsan IYA, Lozhkin HV, Mushkevych MI. Psykholohiya zdorov"ya lyudyny [Psychology of human health]. Luts'k: RVV - Vezha. Volyn. nats. un-tu im. Lesi Ukrayinky, 2011: 430 p. (Ukrainian)

9. Mortsiefer A, Immecke J, Rotthoff T, et al. Summative assessment of undergraduates' communication competence in challenging doctor-patient encounters. Evaluation of the Düsseldorf CoMeDOSCE. Patient Educ Couns. 2014; 95(3): 348-55.

10. Simmenroth-Nayda A, Nolte C, Fischer T, Himmel W. Psychometric properties of the Calgary Cambridge guides to assess communication skills of undergraduate medical students. assess communication skills of und
Int J Med Educ. 2014; 5: 212-218.

11. Brown R, Bylund C. Communication skills training: describing a new conceptual model. Acad Med. 2008; 83(1): 37-44.

12. Fischbeck S, Mauch M, Leschnik E, Beutel ME, Laubach W. Assessment of communication skills with an OSCE among first year medical students. Psychotherapie Psychosomatik Medizinische Psychologie. 2011; 61 (11): 465-471. 


\begin{abstract}
Рeфpepat
УРОВЕНЬ СФОРМИРОВАННОСТИ ОСНОВНЫХ КОММУНИКАТИВНЫХ НАВЫКОВ У СТУДЕНТОВ ПЕРВОГО КУРСА МЕДИЦИНСКОГО ФАКУЛЬТЕТА

Иванченко Е.З., Мельникова О.З., Лурье К.И.

Ключевые слова: первокурсники, коммуникация, эмпатия, конфликтные ситуации

Целью представленной работы было исследование у студентов 1 курса медицинского фракультета уровня сформированности основных коммуникативных навыков, что может служить основой их дальнейшего развития в ходе последующего обучения. Общий уровень коммуникативности студентов оценивали, используя тест «Диагностика коммуникативных и организаторских склонностей», общий уровень эмпатии и степень её проявления в общении с разными категориями людей и в обращении с животными изучали с помощью теста Юсупова И., типы поведения в конфликтах, применив тест Томаса. Результаты исследования обработаны согласно ключам, которые предложены авторами тестов. Показано, что большинство студентов (66\%) имели высокий и очень высокий уровень общей комуникативности, тогда как низкий и очень низкий - только 18\%. Нормальный общий уровень эмпатии выявлен у 91,7\% первокурсников, а у остальных 8,3\% учащихсяон оказался высоким. Наибольшую эмпатию студенты проявляли к родителям (средний уровень 10,1 из 15 возможных баллов), незнакомцам $(9,2)$ и детям $(8,9)$, тогда как к пожилым людям уровень эмпатии составил 6,9 баллов. Определение стратегии разрешения конфликтных ситуаций показало, что чаще всего первокурсники выбирали компромисс (22,5\% парней и 24\% девушек), на втором месте у девушек было избегание (23\%), а у парней - соперничество (21,8\%). Сотрудничество было выбрано, в основном, девушками (19,8\%). Результаты исследования показали, что высокие уровни обшей коммуникации и эмпатии могли способствовать выбору будущей профессии студентами и нуждаются при их последующем обучении только в правильной поддержке, тогда как эмпатию к пожилым людям и выбор наилучшей стратегии разрешения конфликтов в виде сотрудничества сторон необходимо фрормировать и развивать в ходе образовательного и воспитательного процессов в университете.
\end{abstract}

\title{
Рефрерат
}

РІВЕНЬ СФОРМОВАНОСТІ ОСНОВНИХ КОМУНІКАТИВНИХ НАВИЧОК У СТУДЕНТІВ ПЕРШОГО КУРСУ МЕДИЧНОГО ФАКУЛЬТЕТУ

Іванченко О.З., Мельнікова О.З., Лур 'є К.І.

Ключові слова: першокурсник, комунікація, емпатія, конфрліктні ситуації

Метою представленої роботи було дослідження у студентів 1 курсу медичного фракультету рівня сформованості основних комунікативних навичок, що може служити основою їх подальшого розвитку в ході подальшого навчання. Загальний рівень комунікативності студентів оцінювали, використовуючи тест «Діагностика комунікативних і організаторських схильностей», рівень емпатії і ступінь її прояву в спілкуванні з різними категоріями людей і в поводженні з тваринами вивчали за допомогою тесту Юсупова І.М., типи поведінки в конфліктах, застосувавши тест Томаса. Результати дослідження оброблені згідно ключам, які запропоновані авторами тестів. Показано, що більшість студентів (66\%) мали високий і дуже високий рівень загальної комунікативної, тоді як низький і дуже низький - лише $18 \%$. Нормальний загальний рівень емпатії виявлено у 91,7\% першокурсників, а у решти 8,3\% учнів він виявився високим. Найбільшу емпатію студенти проявляли до батьків (середній рівень 10,1 315 можливих балів), незнайомцям $(9,2)$ і дітям $(8,9)$, тоді як до людей похилого віку рівень емпатії склав 6,9 балів. Визначення стратегії вирішення конфліктних ситуацій показало, що найчастіше першокурсники вибирали компроміс (22,5\% хлопців і 24\% дівчат), на другому місці у дівчат було уникнення (23\%), а у хлопців - суперництво (21,8\%). Співпрацю було вибрано, в основному, дівчатами (19,8\%). Результати дослідження показали, що високі рівні загальної комунікації і емпатії могли сприяти вибору майбутньої професії студентами і потребують в ході їх подальшого навчання тільки правильної підтримки, тоді як емпатію до літніх людей і, особливо, вибір найкращої стратегії вирішення конфліктів у вигляді співробітництва сторін необхідно значною мірою формувати і розвивати протягом освітнього і виховного процесів в університеті. 